Прокопенко Т. О., молодший науковий співробітник

(науковий керівник - кандидат ветеринарних наук В. 3. Салата) Державний науково-дослідний інститут із лабораторної діагностики та ветеринарно-санітарної експертизи, м. Київ

\title{
УДОСКОНАЛЕННЯ СИСТЕМИ ВЕТЕРИНАРНОГО РАДІОЛОГІЧНОГО МОНІТОРИНГУ РАДІОАКТИВНОГО ЗАБРУДНЕННЯ СИРОВИНИ ТВАРИННОГО ТА РОСЛИННОГО ПОХОДЖЕННЯ НА ТЕРИТОРІЇ УКРАЇНИ
}

\section{Рецензенти - кандидат ветеринарних наук Г. В. Київська}

Невід'ємним компонентом радіаційної безпеки на 25-му роиі подолання наслідків Чорнобильської катастрофи залишається контроль вмісту радіонуклідів у сільськогосподарській сировині та кормах. Основою радіаційної безпеки є радіологічний контроль $і$ моніторинг радіоактивного забруднення сировини тваринного й рослинного походження та унеможливлення надходження радіонуклідів до організму людини $i$ тварин. Впровадження системи ветеринарного радіологічного моніторингу забезпечить ефективне використання наявних організаційних структур та засобів спостережень за об'єктами ветеринарного нагляду.

Ключові слова: радіологічний моніторинг, радіонукліди, сировина тваринного та рослинного походження.

Постановка проблеми. Поняття радіологічного контролю та моніторингу - різні. Радіологічний контроль - це радіологічні вимірювання, що виконуються для контрольованого об'єкта 3 метою визначення ступеня дотримання принципів радіаційної безпеки, вимог нормативів (включаючи неперевищення контрольних рівнів) або з метою спостережень за станом об'єкта.

Радіологічний моніторинг - регулярні спостереження радіаційної обстановки з метою визначення (контролю) динаміки ії зміни й виявлення аномалій для досліджень і оперативного втручання.

Згідно з Постановою КМУ від 30.03.1998 p. № 391 «Про затвердження Положення про державну систему моніторингу довкілля», система моніторингу $\epsilon$ складовою частиною національної інформаційної інфраструктури, сумісної 3 аналогічними системами інших країн.

Система моніторингу - це відкрита інформаційна система, пріоритетами функціонування якої $є$ захист життєво важливих екологічних інтересів людини і суспільства, збереження природних екосистем, відвернення кризових змін екологічного стану довкілля та запобігання надзвичайним екологічним ситуаціям.
Аналіз останніх публікацій і джерел, у яких започатковано вирішення проблеми. Щодо питань радіологічного моніторингу, у тому числі моніторингу сільськогосподарської продукції, то звіти державних лабораторій ветеринарної медицини дали змогу сформулювати коло питань, які потребують розгляду в ході дослідження. Найголовніше 3 них - це удосконалення системи ветеринарного радіологічного моніторингу в Україні.

За основу удосконалення системи ветеринарного радіологічного моніторингу сільськогосподарської сировини тваринного та рослинного походження нами були прийняті наукові положення, розроблені I. П. Герасимовим [1, 2], Ю. О. Ізраелем [4], В. І. Ізмалковим [3] та ін.

Нами було вивчено й проаналізовано існуючий стан організації та ведення радіологічного контролю і моніторингу в Україні, зокрема, державного моніторингу сільськогосподарської продукції; проведено аналіз законодавчої та нормативної бази з даного питання.

Слід відзначити, що роботи стосовно визначення вмісту радіонуклідів в об'єктах ветеринарного нагляду, які проводяться державними лабораторіями ветеринарної медицини, регламентовані документами, розробленими у 1987 році. Вони застаріли й не відповідають реаліям сьогодення, що склалися після аварії на ЧАЕС. Радіологічні дослідження в Україні нині проводяться відповідно до чинних документів «Положения о радиологическом отделе республиканских, областных (краевых) ветеринарных лабораторий и специализированной радиологической группе районных (межрайонных) ветлабораторий, лабораторий ветсанэкспертизы на рынках, лабораторий предприятий мясной и молочной промышленности системы Госагропрома СССР» та «Программы работы радиологических отделов республиканских, областных (краевых) лабораторий и радиологических групп районных (межрайонных) ветлабораторий, лабораторий вет- 


\section{ВЕТЕРИНАРНА МЕДИЦИНА}

санэкспертизы и производственных лабораторий предприятий мясной и молочной промышленности», затверджених у 1987 році [5].

Аналіз стану системи радіологічного контролю забрудненості сільськогосподарської сировини рослинного та тваринного походження та води для напування тварин із боку Державної ветеринарної й фітосанітарної служби України показав, що існуючий ветеринарний радіологічний контроль не відповідає науковому поняттю «моніторинг».

Наявна програма роботи радіологічних відділів досить чітко регламентована, проте потребує суттєвого уточнення, врахування накопичених даних про радіаційний стан території України через 25 років після аварії на ЧАЕС та сучасних методичних засобів.

Метою роботи було удосконалити систему ветеринарного радіологічного моніторингу радіоактивного забруднення сировини тваринного та рослинного походження на території України.

Завдання дослідження: провести контроль вмісту радіонуклідів у сільськогосподарській сировині та кормах.

Матеріали та методи досліджень. Дані, отримані нами в ході аналізу методичної та законодавчої бази, стали основою для досліджень, спрямованих на удосконалення чинних законодавчих документів щодо радіологічного контролю $з$ метою забезпечення об'єктивніших результатів радіологічних досліджень i оперативної оцінки радіаційного стану забруднених територій та України в цілому.

Результати досліджень. У результаті проведеної роботи було удосконалено діючу «Програму роботи радіологічних відділів...» («Программа работы радиологических отделов республиканских, областных (краевых) лабораторий и радиологических групп районных (межрайонных) ветлабораторий, лабораторий ветсанэкспертизы и производственных лабораторий предприятий мясной и молочной промышленности») 3 урахуванням сучасної методичної бази та наявних сучасних приладів радіологічного контролю. Внаслідок цього нами було розроблено методичні вказівки «Система ветеринарного радіологічного моніторингу (відновлювальний період). Методичні вказівки» [5], затверджені й прийняті до впровадження в практику ветеринарної медицини Науково-методичною радою Державної ветеринарної та фітосанітарної служби України (протокол №4 від 21.12.2011р.).

У зазначених методичних вказівках визначено галузь застосування даних методичних вказівок. Вони призначені для установ Державної вете- ринарної та фітосанітарної служби України, що здійснюють радіологічний моніторинг радіоактивного забруднення сировини тваринного та рослинного походження; слухачів факультетів післядипломного навчання, науковців, викладачів та студентів вищих навчальних закладів IIIIV рівнів акредитації зі спеціальності 6.130501, 8.130501 - «Ветеринарна медицина»; радіологічних підрозділів інших міністерств і відомств в області розповсюдження їх діяльності на радіологічний контроль сировини тваринного та рослинного походження.

Вказівки розроблені з урахуванням радіаційного стану, який склався на території України в результаті аварійних викидів радіоактивних речовин у навколишнє середовище, на основі аналізу даних про рівні вмісту радіоактивних речовин у сировині тваринного та рослинного походження, оцінки розміщення на території країни радіаційно небезпечних об'єктів, а також набутого досвіду щодо організації та проведення ветеринарного радіологічного контролю по всій території Україні і в районах, які постраждали від радіаційних аварій.

Поскільки рослини, тварини та тваринна продукція $є$ основними ланками трофічного ланцюга, то до об' єктів моніторингу ми включили:

1) грубі корми (сіно звичайних й сіяних трав, солома тощо), концентровані корми (комбікорм, зернофураж), соковиті корми (трава сіяна та звичайних угідь, силос);

2) коренеплоди, коренебульбоплоди (картопля, морква, буряки). За ступенем зростання акумуляції радіонуклідів рослини можна розташувати в наступній послідовності: капуста - буряк - картопля - пшениця - природна трав'яна рослинність;

3) гриби та ягоди. Як відомо, хімічний склад рослин і грибів знаходиться в тісній залежності від складу грунту, поскільки вони є відмінними поглиначами всіх доступних хімічних елементів, що містяться в ній, у тому числі й радіонуклідів;

4) продукти тваринництва: молоко, м'ясо, кістки ВРХ, птиця, яйця, риба, мед;

5) воду для напування тварин. Радіонукліди iз забрудненими кормами та водою надходять в організм тварин i, таким чином, сировина тваринного та рослинного походження може бути джерелом надходження радіонуклідів в організм людини.

Оскільки найбільш можливими біологічно значимими забруднювачами у випадку аварії у відновлюваний період $є{ }^{137} \mathrm{Cs}$ та ${ }^{90} \mathrm{Sr}$, то ветеринарний радіологічний моніторинг спрямований на визначення саме цих показників. У даних ме- 


\section{ВЕТЕРИНАРНА МЕДИЦИНА}

тодичних вказівках регламентовано місця відбору проб для досліджень на вміст ${ }^{137} \mathrm{Cs}$ та ${ }^{90} \mathrm{Sr}$, вимірювання потужністі дози гамма-випромінювання на місцевості, від об'єкта ветеринарного нагляду, що відбирається, а також у місці відбору. Наведено визначення контрольних пунктів та їх кількість залежно від місцезнаходження та географічних умов, визначено відповідальність за розробку графіків відбору проб.

Контрольні пункти - господарства, незалежно від форми власності, обрані з урахуванням географічних, грунтово-кліматичних умов, структури тваринництва в регіоні, радіаційної ситуації і розташування радіаційно-небезпечних об'єктів. Контрольні пункти закріплюються за радіологічними відділами регіональних, обласних державних лабораторій ветеринарної медицини та ДНДІЛДВСЕ.

Кількість обраних контрольних пунктів зумовлена однорідністю області за вищевказаними умовами. Чим однорідніша область, тим меншою може бути їх кількість. Орієнтовна кількість контрольних пунктів становить 3-7. За наявності в регіоні АЕC або іншого радіаційно-небезпечного об'єкта, додатково встановлюють три контрольні пункти - в санітарно-захищеній зоні, зоні нагляду і зоні контролю.

Вважаємо за необхідне зазначити, що $з$ метою дієвого й злагодженого функціонування системи ветеринарного радіологічного моніторингу, ми визначили наступне: місцезнаходження контрольних пунктів та графіки 3 конкретними термінами відбору проб для радіологічних досліджень розробляються радіологічними відділами регіональних, обласних державних лабораторій ветеринарної медицини та ДНДІЛДВСЕ і затверджуються начальником Головного управління ветеринарної медицини в області, а проби на місцях відбираються спеціалістами міжрайонних та районних державних лабораторій ветеринарної медицини в контрольних пунктах району згідно з графіками відбору та доставляються до закріплених радіологічних відділів. Заміна контрольних пунктів проводиться лише після узгодження з ДНДІЛДВСЕ.

3 метою забезпечення достовірності вимірювань вмісту радіонуклідів ${ }^{137} \mathrm{Cs}$ та ${ }^{90} \mathrm{Sr}$ у даних вказівках наведені вимоги до приладів, що використовуються для радіологічних досліджень сировини тваринного та рослинного походження.

Для проведення ветеринарного радіологічного моніторингу використовуються радіометричні, спектрометричні та радіохімічні методи аналізу.

Для проведення пробопідготовки та вимірювань питомих активностей радіонуклідів ${ }^{137} \mathrm{Cs}$ та ${ }^{90} \mathrm{Sr}$ у сировині тваринного й рослинного походження допускаються методики виконання вимірювань, що відповідають вимогам забезпечення єдності вимірювань чинних в Україні державних стандартів і забезпечують вірогідність контролю питомих активностей, що характеризується довірчою ймовірністю не нижче 0,95 .

Вважаємо за необхідне зазначити, що в розробленому нами документі особливе місце відведено відбору проб, оскільки саме він суттєво впливає на похибку вимірювання.

Порядок відбору i кількість проб, що забезпечують репрезентативність вибірки контрольованого виду продукції, розроблений нами відповідно до нормативних документів та ГОСТів.

Крім того детально описано процес відбору проб м'яса та кісток, риби, яєць, натурального меду, кормів: коренеплодів, коренебульбоплодів, трави і зеленої маси сільськогосподарських культур, грибів та ягід, води для напування тварин.

Перед відбором проб у контрольних пунктах рекомендується перевіряти однорідність партії продукції, що підлягає дослідженню, шляхом прямого експресного вимірювання рівня гаммавипромінювання, наприклад, приладами СРП68-01, «Супутник», «Сигнал».

За цих умов необхідно дотримуватися постійної відстані від об'єкта дослідження: від грунту 0,7-1,0 м; від скирти, бурту, туш тварин, риби, меду, грибів та ягід тощо - 1-1,5 см; від молока, м'яса і других харчових продуктів - відповідно до чинної Методики експресного визначення об'ємної й питомої активності гамма-випромінюючих нуклідів (гамма-фон) у харчових продуктах за допомогою радіометра типу СРП-6801.

Із метою встановлення чіткої підпорядкованості в ході звітування ми розробили схему звітності щодо ветеринарного радіологічного моніторингу.

Звіт про результати досліджень за рік за встановленою формою, довідку про радіаційний стан на підконтрольній території в звітному році представляють:

- радіологічні відділи регіональних, обласних лабораторій ветеринарної медицини;

- Державному науково-дослідному інституту iз лабораторної діагностики та ветеринарносанітарної експертизи до 1 лютого наступного за звітним періодом року;

- Державний науково-дослідний інститут із лабораторної діагностики та ветеринарносанітарної експертизи - в Державну ветеринарну та фітосанітарну службу України до 1 березня наступного за звітним періодом року. 


\section{ВЕТЕРИНАРНА МЕДИЦИНА}

Висновки. Впровадження системи ветеринарного радіологічного моніторингу забезпечить:

1. Реалізацію Постанови Кабінету Міністрів України від 30 березня 1998 р. № 391 «Про затвердження Положення про державну систему моніторингу довкілля» Державною ветеринарною та фітосанітарною службою Міністерства аграрної політики та продовольства.

2. Ефективне використання наявних органі-

\section{БІБЛІОГРАФІЯ}

1. Герасимов И. П. Научные основы современного мониторинга окружающей среды // Изд. АН СССР. - Серия «География», 1975. - № 3. C. 13-25.

2. Герасимов И. П. Мониторинг окружающей среды / И. П. Герасимов // Общие проблемы географии и моделирование геосистем: Тр. XXII Международного географического конгресса. М. : Наука, 1976. - С. 15-34.

3. Измалков В. И. Экологическая безопасность, методология прогнозирования антропо- заційних структур та засобів спостережень за об'єктами ветеринарного нагляду.

3. Конкретизацію та посилення відповідальності за повноту, своєчасність і достовірність переданої інформації.

4. Колективне використання інформаційних ресурсів та комунікаційних засобів.

5. Безкоштовний обмін інформацією серед користувачів на всіх рівнях.

генных загрязнений и основы построения химического мониторинга. - СПб, 1994. - 131 с.

4. Израэль Ю. А. Экология и контроль состояния природной среды. - М. : Гидрометеоиздат, 1984. - $560 \mathrm{c}$.

5. Прокопенко Т. О., Салата В. 3. Система ветеринарного радіологічного моніторингу (відновлювальний період). Методичні вказівки / [Т. О. Прокопенко, В. 3. Салата]. - К. : ДНДІ ЛДВСЕ, 2012. -26 с. 